\title{
Development of a low cost 3D printer indicated to prototyping objects
}

\section{Desenvolvimento de uma impressora 3D de baixo custo para prototipagem de objetos}

\author{
Rafael Zucca $^{1}$; Rodrigo Couto Santos ${ }^{2}$; Juliano Lovatto ${ }^{3}$; \\ Rafaela Silva Cesca ${ }^{4}$; Felipo Lovatto ${ }^{5}$
}

\begin{abstract}
The industry 4.0 is increasingly changing the productive chain, and, therefore, the sustainable technological development. In this context, 3D printers are among the trends which ought to promote opportunities of new businesses, as producing customized and not always available products etc. In countries similar to Brazil, commercial 3D printers still present a high cost. Thus, this study aimed to develop a low cost 3D printer using the self-replicating method RepRap -; to test; calibrate; and print an object in order to compare the printer built to a similar certified commercial one. A printer similar to the model Prusa i3 has been built with the firmware Marlin, used to control its components and software Repetier $\AA$, intended to configuration and control. The first result was the development of a 3D printer configured and calibrated, enabling a meaningful comparison between the printing processes of a low cost $3 \mathrm{D}$ printer and a certificated commercial printer. The research concluded that it is possible to develop a low cost RepRap 3D printer, when it is compared to a certified commercial printer, presenting identical characteristics, especially regarding the final quality of the printing process.
\end{abstract}

Keywords: Industry 4.0. Model RepRap. Sustainable technology.

\section{Resumo}

A indústria 4.0 vem impactando a cadeia produtiva refletindo no desenvolvimento tecnológico sustentável, sendo que o uso da impressão em 3D se encontra entre as tendências que devem criar novas oportunidades de negócios, como confecção de peças personalizadas e de difícil aquisição, entre outras. Em países como Brasil a impressora 3D comercial ainda possui elevado custo. Assim, este estudo teve por objetivo desenvolver uma impressora 3D de baixo custo, aplicando o método RepRap de auto replicação, testar, calibrar e imprimir peça para comparar com uma impressora comercial similar certificada. Realizou-se a montagem de uma impressora similar ao modelo Prusa i3 com o firmware Marlin utilizado para controle de seus componentes e software Repetier ${ }^{\circledR}$ para sua configuração e controle. Como resultado foi desenvolvida a impressora 3D configurada e calibrada realizando-se a comparação de qualidade imprimindo uma peça na impressora 3D de baixo custo e em impressora comercial certificada. Também foram fabricadas peças como tela protetora e suporte para filamento, visando a melhoria do projeto. Com esta pesquisa foi possível concluir que é possível desenvolver uma impressora 3D RepRap de baixo custo se comparada à impressora comercial certificada com características idênticas quanto a precisão na qualidade final da impressão.

Palavras-chave: Indústria 4.0. Modelo RepRap. Tecnologia sustentável.

\footnotetext{
${ }^{1}$ Me., Depto de Engenharia Agrícola, UFGD, Dourados, MS, Brasil. E-mail: rafael-zucca@ hotmail.com

${ }^{2}$ Prof. Dr., Faculdade de Ciências Agrárias, UFGD, Dourados, MS, Brasil. E-mail: rodrigocouto@ufgd.edu.br

${ }^{3}$ Me., Prefeitura Universitária, UFGD, Dourados, MS, Brasil. E-mail: julianolovatto@ ufgd.edu.br

${ }^{4}$ Mestranda, Faculdade de Ciências Agrárias, UFGD, Dourados, MS, Brasil. E-mail; rafaela.s.cesca@ hotmail.com

${ }^{5}$ Prof. Esp. IFMS, Jardim, MS, Brasil. E-mail: lovatto_felipo@ hotmail.com
} 


\section{Introduction}

The first studies with 3D printers were performed in 1970 , and the beginning of the printing industry is dated from the end of 80's, when these machines presented high costs. According to Kietzmann, Pitt and Berthon (2015), printing methods evolved from the final design being shaped by withdrawing material (subtractive method) to a more modern way, in which printings procedures consisted in depositing material layer-by-layer.

Hausman and Horne (2014) described that 3D printings evolved rapidly after a method known as RepRap had been developed, which is the first method of fast selfreplicating prototyping, recycling engines and materials, enabling part of the components to be printed in order to produce new 3D printers or improve those already produced.

In the beginning of the $21^{\text {st }}$ century, when smaller and more powerful engines were developed and hardware and software were increasingly more sophisticated, besides the possibility of digitally interconnecting daily objects using internet - also known as "internet of things" (IoT) -, the industry started a revolution which directly impacted on society, economy and competitiveness, from which emerged the concept of industry 4.0 (SCHWAB, 2017).

Industry 4.0 is strongly impacting on the productive chain, and, therefore, directly impacting on the sustainable technology development. According to Agostini and Filippini (2019), 3D printing is among the trends which, until 2025, should create new opportunities of businesses, prototyping in $3 \mathrm{D}$ items and objects, using more sophisticated materials and consolidating prototyping branch into different sectors and not only into industry, such as health, agribusiness, household use etc.

$3 \mathrm{D}$ prototyping is being constantly improved (KALSOOM; NESTERENKO; PAULL, 2018) and has demonstrated a great potential to change the current productive model, enabling items, structures, customized devices and objects - which present different geometries -, to be built, and for which the standard manufacturing technics would not be indicated, in order to facilitate the building process.

Woodson, Alcantara and Nascimento (2019) researched the costs of $3 \mathrm{D}$ printing processes in Brazil. At the end of the study, they concluded that $3 \mathrm{D}$ printing technology presents a constant increase worldwide, although in countries as Brazil it faces the high costs of commercial printers. Thus, this study is important to show that is possible to carry out a low cost and easy to perform project.
This research aimed to develop a low cost 3D printer - applying the self-replicating method RepRap -; to test printers' working; and to calibrate and print items, comparing their final quality with the items printed by a similar national and certified printer.

\section{Materials and methods}

The study was carried on February, 2019, in the Agricultural Sciences College (Faculdade de Ciências Agrárias - FCA) of the Federal University of Grande Dourados (UFGD), at the Rural Buildings and Ambiance Laboratory, located in the city of Dourados, in the state of Mato Grosso do Sul, Brazil. The project development followed the flowchart in Figure 1.

Figure 1 - Flow diagram of the 3D Printer Mounting Stage

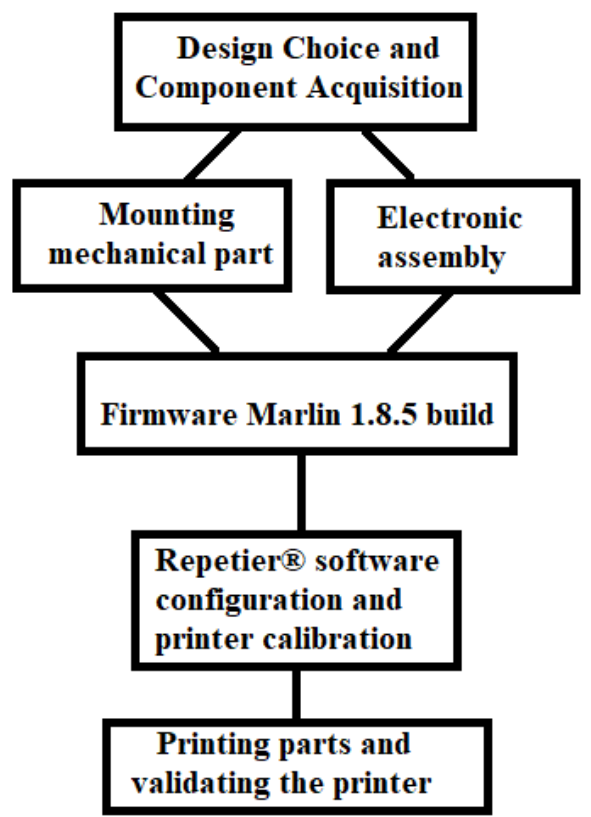

Source: The authors

References data of 3D printers projects were obtained from the science database of SciELO (Scientific Eletronic Library Online) Science Direct, prioritizing the more relevant national articles issued until 2019. Next, a printer Graber i3 was built, similar to model Prusa i3, using the items of the projects researched, see Table 1.

After all items had been acquired, the project of the printer's building begun, Figure 2 . In the first stage, the fiberboard structure was built and attached, together with the mechanic part of the machine, to the guides and threaded bars (A) and afterward, to the bearings (B).

According to Figure 3, the electric/electronic part, which is responsible for the printers' working, was built in the next stage which comprised the following steps: 
connection of the engines with the board Arduino/Ramps 1.4 (A); connection of the heated table (B); the whole power connection of the printer performed by a $12 \mathrm{v}$ source (C); connection of the display (D); nozzle extruder Hotend $(\mathrm{E})$; cooler $(\mathrm{F})$; and endstops $(\mathrm{G})$.

Table 1 - List of items defined in the initial purpose of the low cost $3 \mathrm{D}$ printer project

\begin{tabular}{lc}
\hline Quantity & Itens \\
\hline 1 & Switched-mode power supply \\
1 & Fiberboard structure \\
1 & Arduino MEGA 2560+Ramps 1.4 \\
4 & Driver A4988 \\
1 & Heated Table Pcb Mk2b Dual \\
& Power+Thermistor 100k \\
3 & End Stop, limit switch device \\
5 & Step motor \\
1 & Nozzle-Hotend Allmetal 1.75mm Nozzle \\
1 & 0.4mm+Thermistor 100k \\
2 & LCD controller and SD card \\
1 & Belts, Pulleys and Bearings 608zz \\
6 & Mini Cooler \\
10 & Rectified axis fabricated in steel 8mm \\
1 & Linear bearings LMU 8mm \\
\hline
\end{tabular}

Source: The authors.

Figure 2-Building of the structure and mechanic part of the $3 \mathrm{D}$ printer

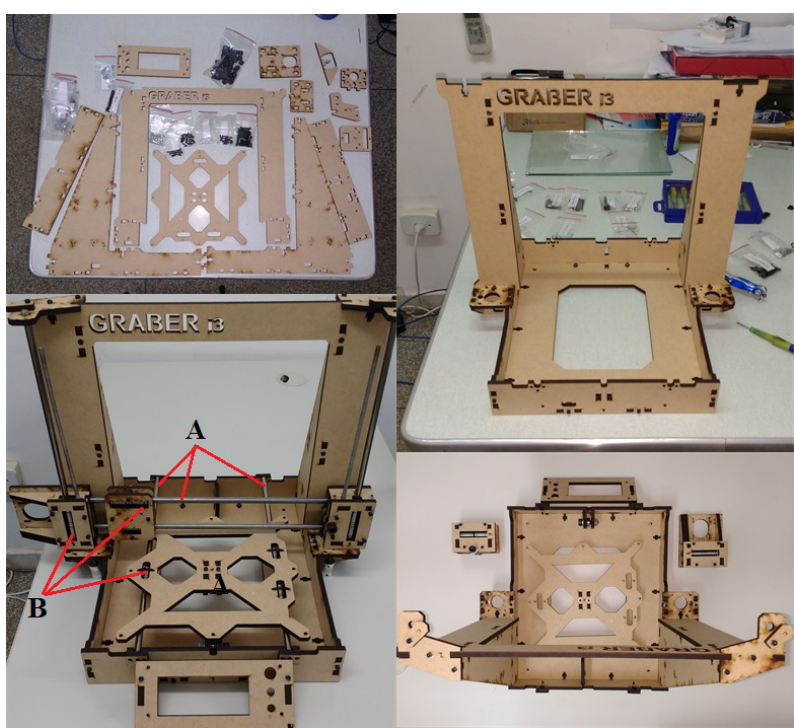

Source: The authors.

The Firmware Marlin 1.8.5 was used to control all items of the 3D printer. This firmware is free and improved by 3D RepRap printers, the same used in this project. It is easy to configure, and presents license GNUGPLv3. The firmware was opened via software Arduino IDE, compiled and configured in Arduino Mega 2560, used in the low cost 3D printer.

Repetier ${ }^{\circledR}$ a basic Host software, compatible with most part of firmware used in 3D printers was used, in order to configure and control the 3D printer. This software performed the basic printer's configurations, like its dimensions, table temperature and nozzle extruder.

With the printer completely assembled and configured, the first tests and calibrations were made. The axes X, Y and $\mathrm{Z}$ were manually leveled, measuring the distance of the extruder nozzle in all ends of the table and in the center of it, thus securing the exact distance by tightening or loosening the screws in all four extremities, such distance was equivalent to the thickness of a sheet of paper, so the Endstop of the $\mathrm{Z}$ axis was fixed at the point 0 .

\section{Results and discussion}

A 3D printer, Figure 4, was developed through this research. It was built using RepRap, which is a low cost and easy to perform method.

After the calibration of the 3D printer's axes and motors has been concluded, the first printing was prepared. Repetier ${ }^{\circledR}$ was already configured, as shown in Figure 5. This software is the communication channel between printer and computer, converting the G-Code into Cartesian coordinates of the printer's printing area, which was, in this project, $200 \mathrm{~mm}$ (X, width) $\mathrm{x} 200 \mathrm{~mm}$ (Y, depth) $\mathrm{x}$ $170 \mathrm{mmm}$ (Z, height).

As can be seen in Figure 5, several commands were pre-set according to the recommendations for the type of filament that was used, in this case ABS (Acrylonitrile Butadiene Styrene), such as table temperature $\left(110^{\circ} \mathrm{C}\right)$ and extruder nozzle $\left(225^{\circ} \mathrm{C}\right)$, printing speed of approximately $25 \mathrm{~mm} / \mathrm{s}$, being fixed at the slowest with 10 and the fast with $50 \mathrm{~mm} / \mathrm{s}$, the same value used for filling the layers, and height of the layers of $0.2 \mathrm{~mm}$. According to Keaveney, Connolly and O'Cearbhaill (2018) there must be a rigorous calibration procedure so that the $3 \mathrm{D}$ printer can reproduce parts with the fidelity described in the software they are connected to. Thus, after entering the commands the printer has gone through the adjustment process aiming at the best possible print quality.

Since the configurations were concluded, the object was prepared through slicing, aiming the first printing, using software Repetier®. The printer was checked in order to verify if it comprised with the dimensional requirements of the 3D file, as shown in Figure 6. Software 
Figure 3 - Electric scheme Ramps 1.4 and Arduino Mega 2560

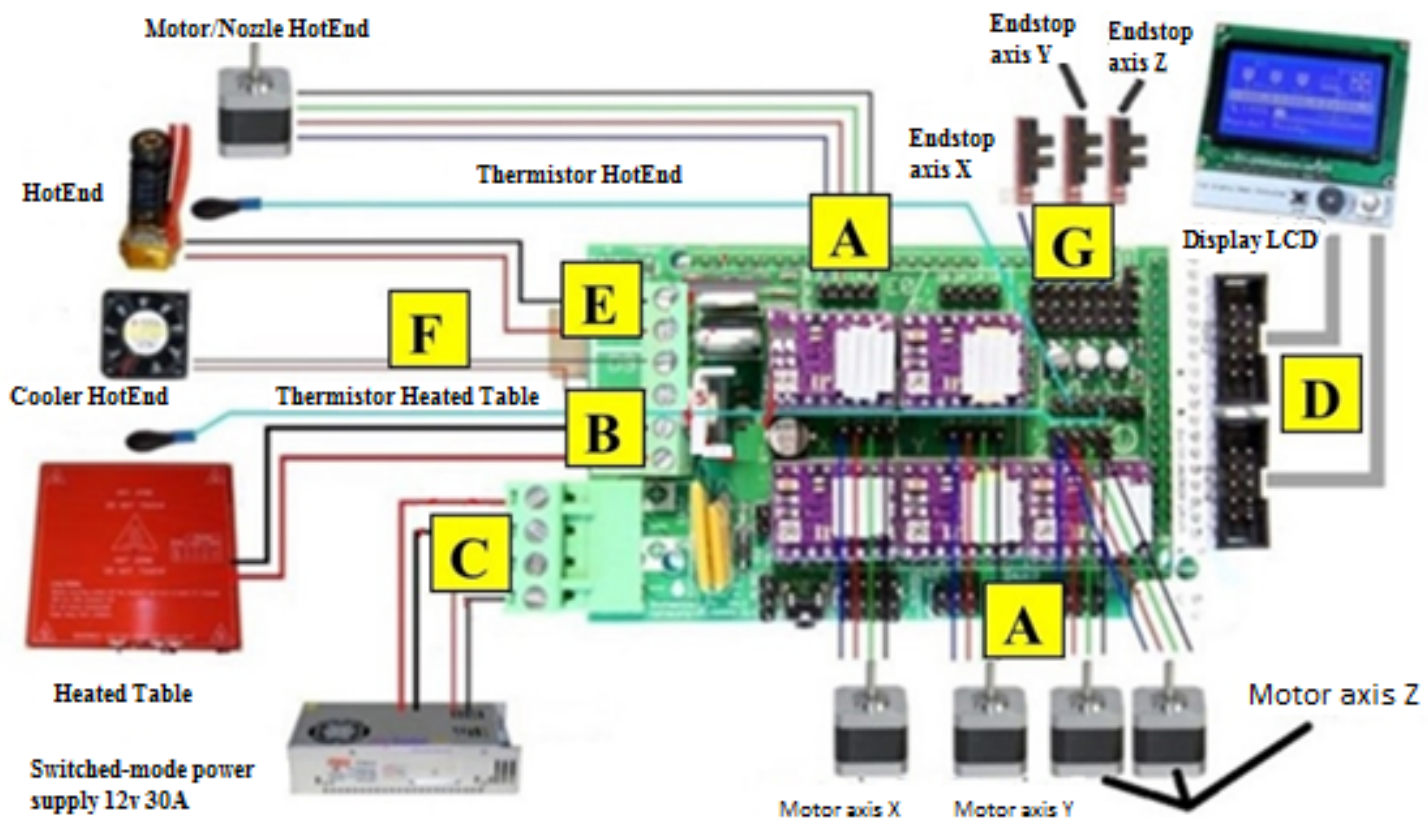

Source: REPRAP, (2018). Adapted by the authors.

Figure 4 - Low cost 3D RepRap printer

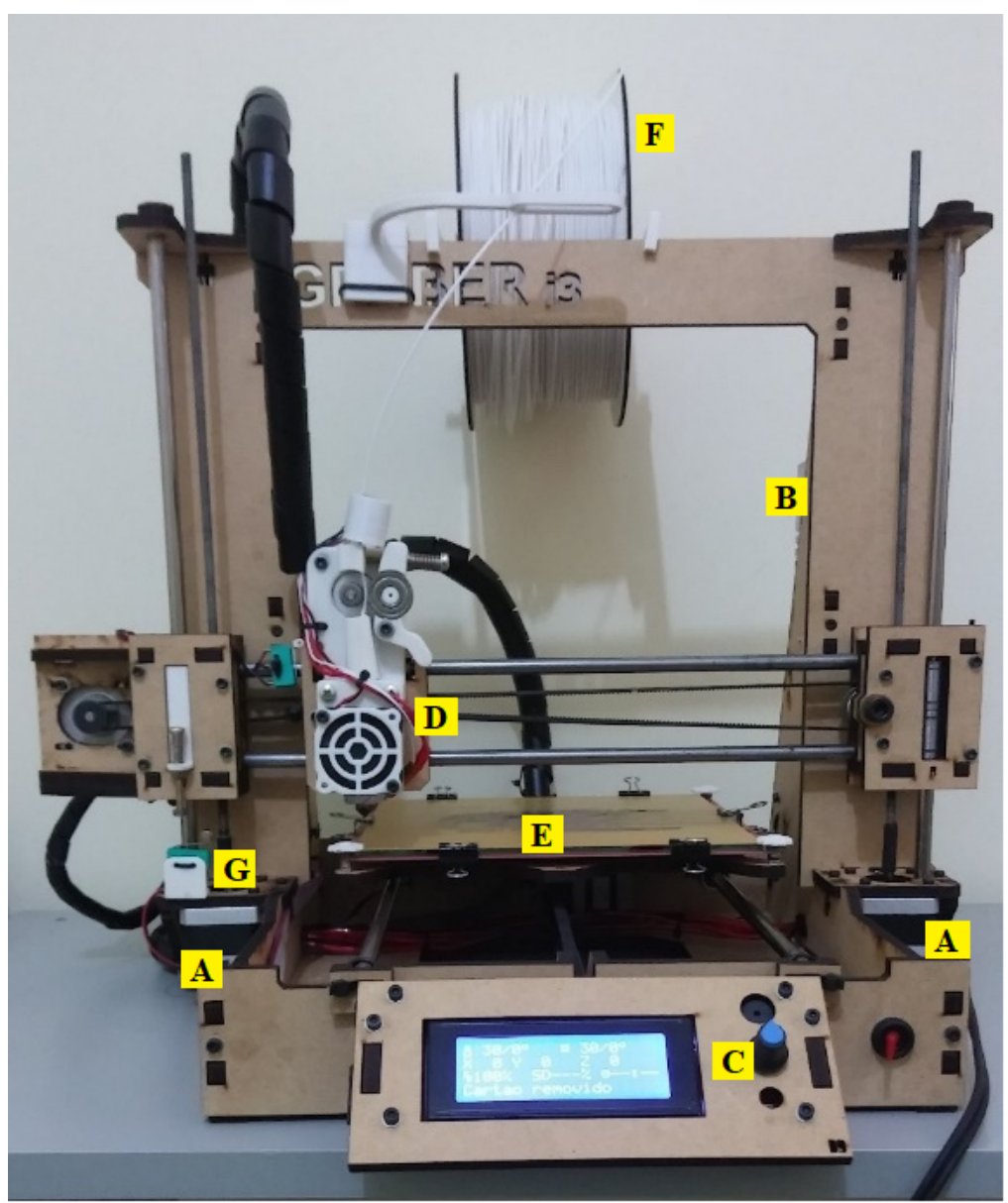

A - Motor Nema 17

B - Switched-Mode Power

Supply $12 \mathrm{v} 30 \mathrm{~A}$

C - Diplay LCD

D - Hotend/Cooler Hotend

E - Heated Table

F - Filament ABS

$\mathrm{G}$ - Endstop

Source: The authors.

and hardware, and even the structure were verified in order to identify eventual problems, enabling to save the object to be printed in the SD card and, then, begin the printing process.
For validation of the 3D printer, as stated by Keaveney, Connolly and O'Cearbhaill (2018) certified printer was used to perform the comparison of printed parts, being calibrated and configured with the same parameters of the 
Figure 5 - 3D printer's configurations using Repetier ${ }^{\circledR}$

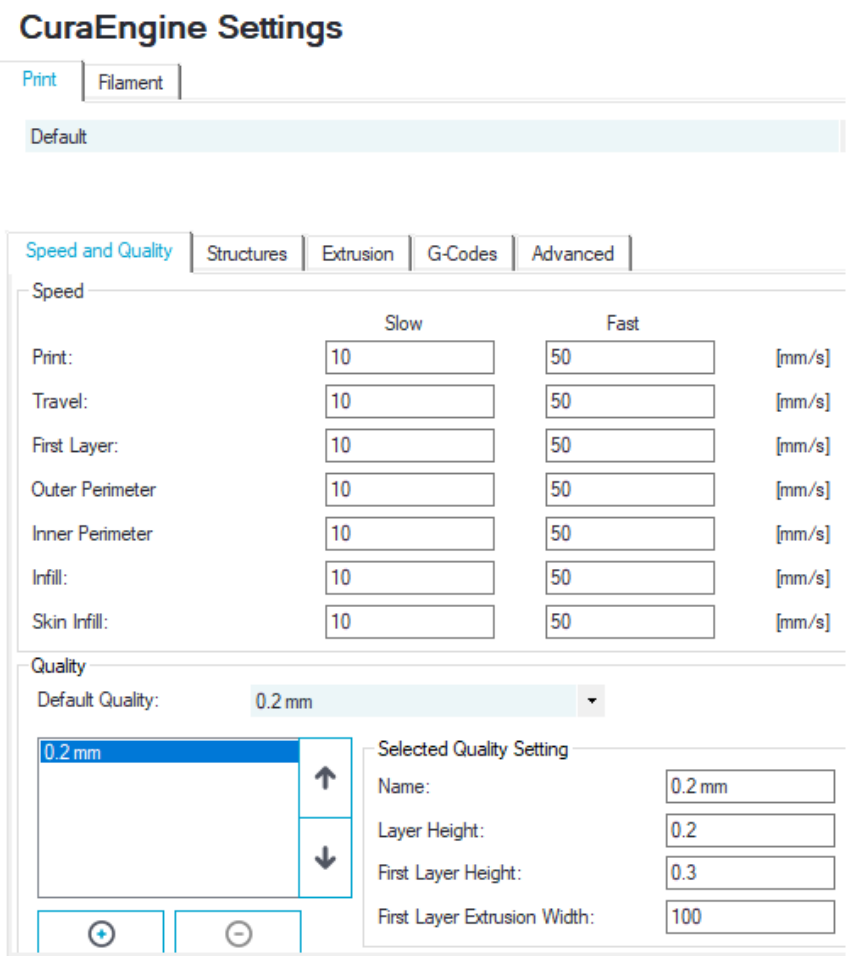

\section{CuraEngine Settings}

Print Filament

Default

$\begin{array}{ll}\text { Filament } & \\ \text { Filament Diameter: } & 1.75 \\ \text { Flow: } & 100 \\ & {[\%]}\end{array}$

Temperature

Print Temperature:

$\begin{array}{ll}225 & {[' C]} \\ 110 & {[C]}\end{array}$

\section{Cooling}

Min. Fan Speed:

Max. Fan Speed:

Minimum Layer Time:

\begin{tabular}{ll}
\hline 50 & {$[\%]$} \\
\hline 100 & {$[\%]$} \\
\hline 5 & {$[s]$} \\
\hline
\end{tabular}

Source: The authors.

Figure 6 - First object printed in the 3D printer, using software Repetier ${ }^{\circ}$

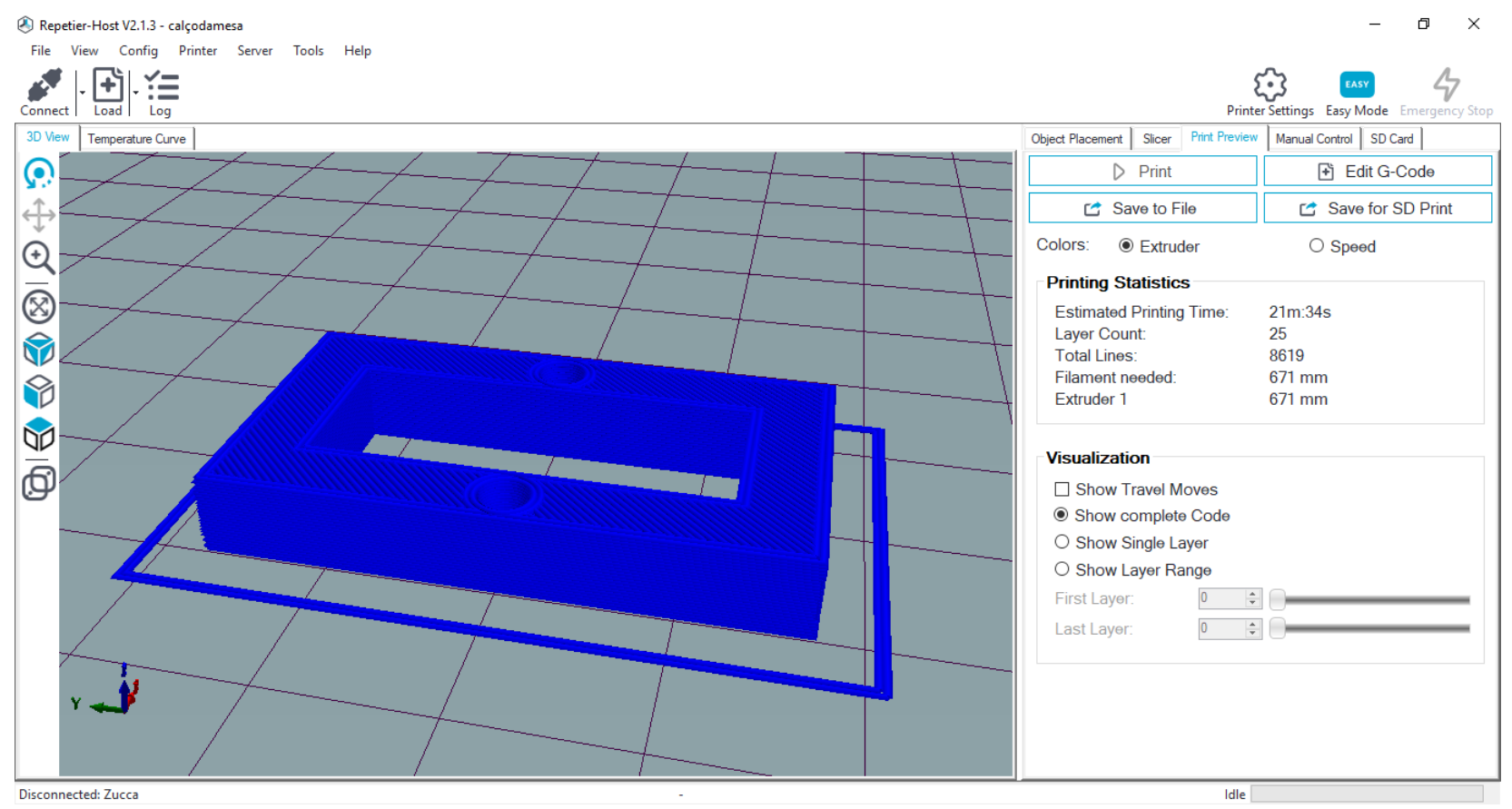

Source: The authors.

developed printer, having the same characteristics (heated table size, engine numbers, nozzle type, material used (ABS). The final quality of the almost identical parts was obtained, as shown in Figure 7, demonstrating that it is possible to develop a low-cost 3D printer with the same quality and purpose of certified printers that are already commercially marketed.
Figure 6 shows the information and the already sliced piece of the part to be printed. On the right side are the data related to print statistics, such as the estimated time of printing, the total number of layers, the amount of material (ABS) to be used in printing, among others.

Figure 7 shows the quality of the first object printed by the low cost $3 \mathrm{D}$ printer (B) compared to the same object 
Figure 7 - Comparison of the printed objects. (A) - object printed by a commercial and certified 3D printer; and (B) object printed by a low cost $3 \mathrm{D}$ printer

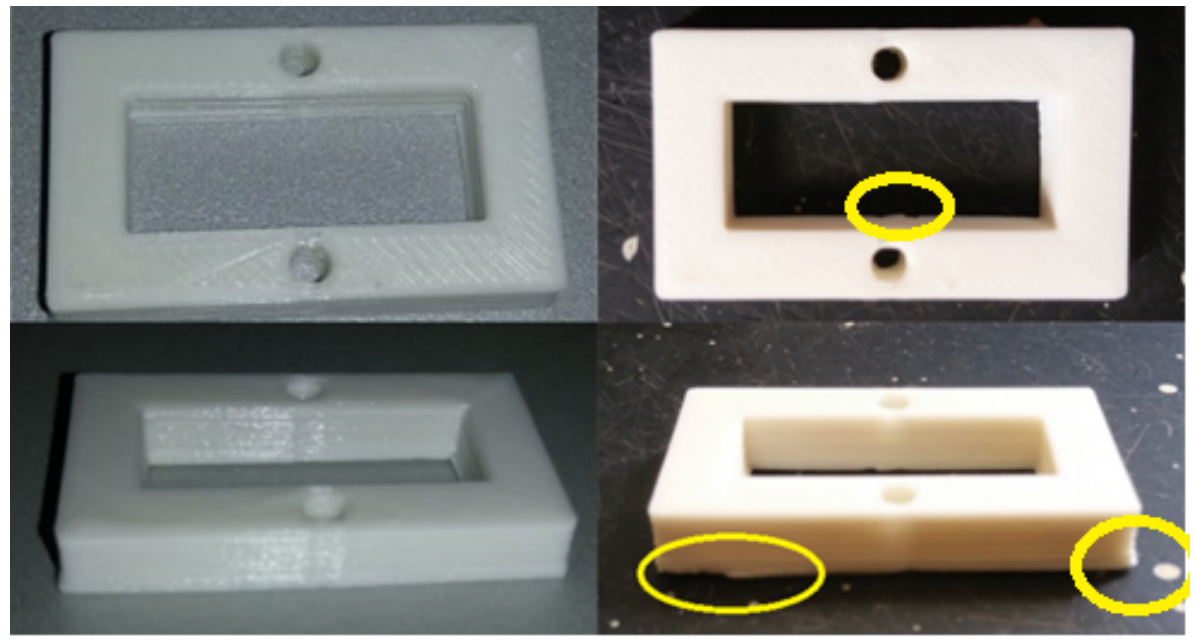

(A)

(B)

Source: The authors.

Figure 8 - Parts, printed by the 3D printer, built and used in the same project

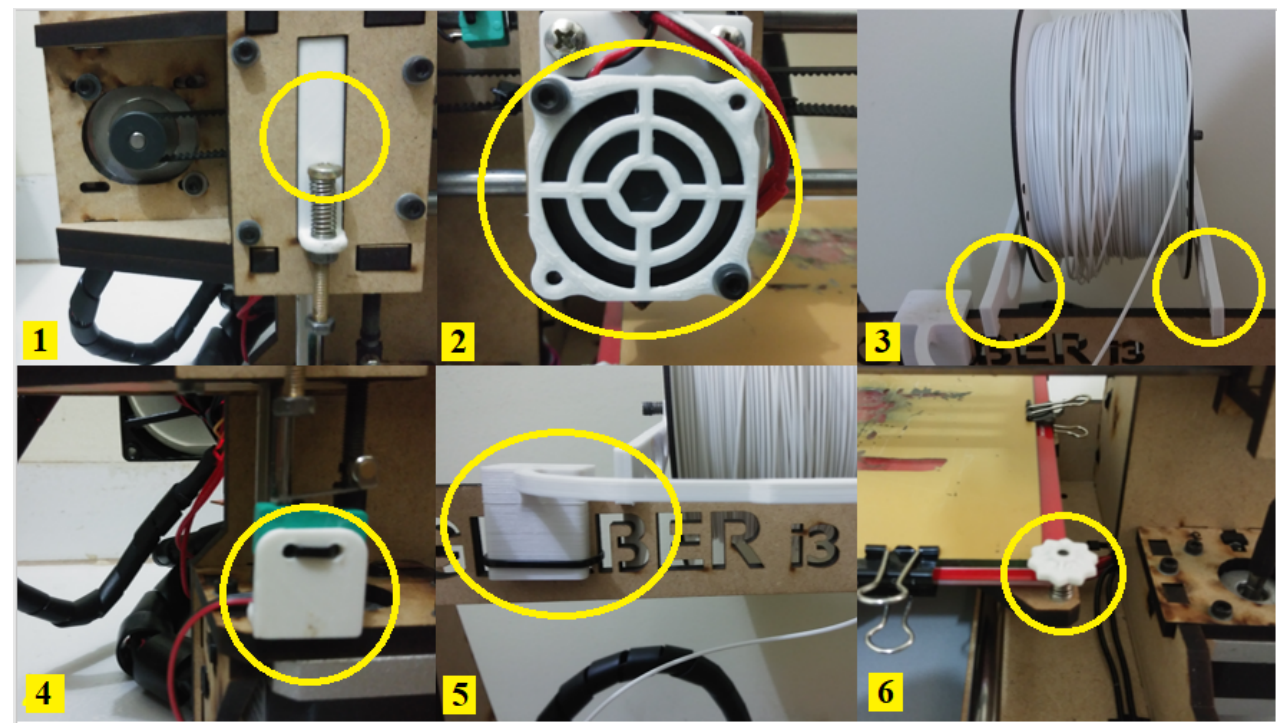

Source: The authors.

printed by a certified 3D printer, model Prusa i3 (A), with the same characteristics of the low cost prototype.

A pachymeter was used to compare the two objects printed, represented by Figure 6, and the following results were verified: both objects presented the same thickness $(5 \mathrm{~mm})$; length $(35 \mathrm{~mm})$; width $(20 \mathrm{~mm})$; diameter of the holes $(3 \mathrm{~mm})$; and finishing in the layers. Nevertheless, Figure 8 shows that the object B, printed by the low cost printer, presented a small amount of residual material in the beginning of the printing (highlighted in yellow), caused by an insignificant unevenness in one of the heated table ends, which was repaired after the printing conclusion, during the table calibration process.

Thus, the study demonstrated that is possible to build a low cost $3 \mathrm{D}$ printer presenting the same quality as a commercial and certified one, but investing 3 times less than the investments to build a commercial and certified Prusa i3, used in the comparison performed in this study. Bagliotti and Gasparotto (2017) have also built a low cost 3D printer, using the same concept: RepRap, and concluded, in the end of their research, that such trend enables manufacturing printers presenting the same quality of the commercial ones, but with less investments. Second Talataisong et al. (2018), the commercial costs of 3D printers are one of the barriers to this kind of product be widely used by industry, agribusiness or enthusiasts in this subject.

The total cost of the project was $\mathrm{R} \$ 1126.10$, acquiring all the components in the national market, compared to the international market, if components purchased in China were used the cost of the project would reduce in almost half $\mathrm{R} \$ 586.29$. 
When comparing the value with that of $3 \mathrm{D}$ printers similar to the project, already assembled and marketed in the domestic market would cost R $\$ 1840,00$ and in China $\mathrm{R} \$ 813,52$, it is observed that the project developed had a cost of a little more of $\mathrm{R} \$ 713$ less if one chooses to buy a printer assembled and marketed in the national market, and if the components were bought in the international market, it would be cheaper to assemble a printer buying the components separately, than to buy it already ready.

Figure 8 shows that the printer was used to build its own parts, aiming the project improvement. Some parts, as the support to regulate axis $\mathrm{Z}$ with the EndStop (1), Mini Cooler metal filter (2), support for the filament roll (3), support for the axis Z EndStop (4), filament guide (5) and the part which regulates the table (6) were printed. Such fact made the prototype closer to the commercial model. Zi et al. (2019) affirmed that 3D printing technologies have developed significantly after the system RepRap creation, which is used to self-replicating and the creation of low cost projects able to print several parts to be used in manufacturing of other 3D printers or to perform improvements in the printers already in use.

Zucca et al. (2018) affirm that 3D prototyping can be used not only by industry or enthusiasts, but also in several sectors as agrobusiness and different engineering fields, contributing to promote changes in the productive and services processes, and serving as a post-revolution 4.0 daily tool, comprising the production of customized, replacement, and no longer manufactured objects, or just those intended to be stored.

\section{Conclusion}

It is possible to develop a 3D printer RepRap, using low cost embedded systems, similar to the commercial and certified printers.

The comparison between the object printed by the low cost 3D printer developed and the Prusa i3 commercially certified presented identical characteristics regarding an accurate final quality of the object.

From an economic point of view, the development of the RepRap 3D printer proved to be advantageous, reducing the cost of practically half of the value that would be invested in the purchase of a 3D printer sold on the national market, with the option to reduce the project costs using in its assembly imported components.

\section{References}

AGOSTINI, L.; FILIPPINI, R. Organizational and managerial challenges in the path toward Industry 4.0. European Journal of Innovation Management, UK, v. 22, n. 3, p.406-421, 2019.

LEER, B. V. Towards the ultimate conservative difference scheme. iv. a new approach to numerical convection. Journal of Computational Physics, v. 23, n. 3, p. 276 - 299, 1977. ISSN 0021-9991. Https://doi.org/10.1016/j.jcp.2010.12.032.

BAGLIOTTI, I. R.; GASPAROTTO, A. M. S. O processo de produção de uma impressora 3D de baixo custo reprap com tecnologia fused filament fabrication. Revista Interface Tecnológica, Taquaritinga, SP, v. 14, n. 1, p. 1-15, 2017.

HAUSMAN, K. K.; HORNE, R. 3D printing for dummies. New Jersey: John Wiley e Sons, 2014.

KALSOOM, U.; NESTERENKO, P. N.; PAULL, B. Current and future impact of 3D printing on the separation sciences. Trac Trends in Analytical Chemistry, [Amsterdam], v. 14, n. 1, p. 15-30, 2018.

KEAVENEY, S.; CONNOLLY, P.; O'CEARBHAILL, E. D. Kinematic error modeling and error compensation of desktop 3D printer. Nanotechnology and Precision Engineering, New York, v. 1, n. 3, p. 180-186, 2018.

KIETZMANN, J.; PITT, L.; BERTHON, P. Disruptions decisions and destinations: enter the age. of 3D printing. and additive. manufacturing. Business Horizons, Greenwich, v. 58, n. 2, p. 209-215, 2015.

REPRAP. RepRap options. 2018. Available in: https://reprap.org/wiki/RepRapOptions. Acess in: 26 dec. 2018.

SCHWAB, K. The fourth industrial revolution. Crown Business, London, v.2, p. 194, 2017.

TALATAISONG, W.; ISMAEEL, R.; MARQUES, T. H.; MOUSAVI, S. A.; BERESNA, M.; GOUVEIA, M. A.; BRAMBILLA, G. Mid-IR Hollow-core microstructured fiber drawn from a 3D printed PETG preform. Scientific reports, London, v. 8, n. 1, p. 8113, 2018.

ZI, B.; WANG. N.; Q. S.; BAO, K. Design, stiffness analysis and experimental study of a cable-driven parallel 3D printer. Mechanism and Machine Theory, New York, v. 132, p. 207-222, 2019. 
ZUCCA, R.; SANTOS, R. C.; LOVATTO, J; LOVATTO,

F; CARMIATO, A. S. Estudo da viabilidade do uso de prototipagem rápida $3 \mathrm{D}$ em processos produtivos no meio rural. Enciclopédia Biosfera, Goiania, v. 15, n.28, p. 517 532,2018
WOODSON, T.; ALCANTARA, J. T.; NASCIMENTO, M. S. Is 3D printing an inclusive innovation: An examination of $3 \mathrm{D}$ printing in Brazil. Technovation, Essex, $\mathrm{v}$. 80-81, p. 54-62, 2019. 